Research Article

\title{
Modeling Tile Drainage Outflow in Thin Agricultural Soils with Impermeable under Layer in Newfoundland and Labrador, Canada
}

Lordwin Girish Kumar Jeyakumar ${ }^{1,}{ }^{\ddagger}$, David B. McKenzie ${ }^{1, *}$, Yuanmei Zhang ${ }^{1, \#}$, Lakshman Galagedara

2, Shabtai Bittman ${ }^{3}$, Derek Hunt ${ }^{3}$

1. St. John's Research and Development Centre, Agriculture and Agri-Food Canada, 204 Brookfield Road, St. John's, NL, A1E 0B2, Canada; E-Mails: lordwingirish@gmail.com;

david.mckenzie@canada.ca; yz7106@mun.ca

2. School of Science and the Environment, Memorial University of Newfoundland, Corner Brook, $\mathrm{NL}, \mathrm{A} 2 \mathrm{H}$ 5G4, Canada; E-Mail: Igalagedara@grenfell.mun.ca

3. Agassiz Research and Development Centre, Agriculture and Agri-Food Canada, Agassiz, BC VOM 1A0, Canada; E-Mails: shabtai.bittman@canada.ca; derek.hunt@canada.ca

¥ Other Affiliation: Nova Scotia Community College, School of Technology and Environment, 80 Mawiomi Place, Dartmouth, Nova Scotia, Canada B2Y 0A5/Independent Researcher, 6 Swanton Drive, Dartmouth, NS B2W 2C4

\# Other Affiliation: Independent Researcher, 9 Foran Street, St. John's, NL A1E 4E9

* Correspondence: David McKenzie; E-Mail: david.mckenzie@canada.ca

Academic Editor: Nicole Mölders

Special Issue: Climate Change and Land

Adv Environ Eng Res

2021, volume 2, issue 2

doi:10.21926/aeer.2102016
Received: December 30, 2020

Accepted: June 21, 2021

Published: June 30, 2021

\begin{abstract}
Subsurface tile drainage installation helps to maintain water table levels and to meet adequate crop moisture requirements. Artificial subsurface drainage continues to be a common practice in Newfoundland and Labrador (NL) and elsewhere around the world. The main objective of this study was to evaluate the performance of DRAINMOD in simulating water table depth (WTD) and water outflow from tile drained agricultural fields. This site on the Avalon Peninsula of Eastern Newfoundland has a rolling landscape with predominantly
\end{abstract}

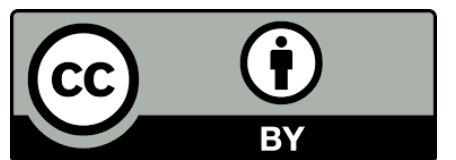

(C) 2021 by the author. This is an open access article distributed under the conditions of the Creative Commons by Attribution License, which permits unrestricted use, distribution, and reproduction in any medium or format, provided the original work is correctly cited. 
Podzolic soils. The tile drainage was installed at $1.0 \mathrm{~m}$ deep and spaced $12 \mathrm{~m}$ apart. Drainage outflows (two per plot) from twelve experimental plots ( $32 \mathrm{~m} \times 60 \mathrm{~m}$ each) were monitored for two years. The simulated WTD ranged from $140 \mathrm{~cm}$ to $160 \mathrm{~cm}$ during rainfall season. The performance of the model was evaluated by the Index of agreement (IOA). It was 0.600 in 2017 and 0.559 in 2018. The result was considered to have acceptable accuracy, which can help to design or evaluate subsurface drainage systems in NL, Canada. However, further evaluation including additional sites are necessary to ensure optimum drainage design parameters for the major agricultural soils.

\section{Keywords}

Tile drainage; modeling; DRAINMOD; forage; water table

\section{Introduction}

Subsurface tile drainage is typically used in agricultural fields to improve soil aeration by removing excess water, which is significantly beneficial for maintaining the desired water level in poorly drained agricultural lands [1-3]. This is considered an effective and important practice in the field of agricultural water management to facilitate farm operations, especially in cold climatic regions and soil systems [4]. There is a need for better agricultural water management systems if the production capacity of agricultural soils is to be optimized in the boreal environment. It is evident that the soil systems are more complex due to great variations of non-linear processes occur at different rates [5]. Agricultural drainage has several well documented benefits for improving the condition of land for farming operations including better trafficability of soils, permitting farmers to begin field operations earlier in the spring and continue later into the fall $[6,7]$. Improved drainage [8] is often needed in NL soils is obvious since to help remove surplus water due to precipitation (1000 to $1600 \mathrm{~mm}$ annually) greatly exceeding ET. Shallow topsoil with impermeable layers at shallow depths characteristic of NL soils compound the drainage problems. Systematic drainage systems such as tiles improve field drainage [9].

In Newfoundland, the efficiency and productivity of agricultural lands depend on the artificial drainage in most of the farms because it can secure the operation of planting and harvesting without delayed during the wet years. However, the performance of artificial drainage [10] is affected by several factors including soil, crop, and climate and practical factors including abundance of stones. Design and evaluation of the long-term performance of a drainage system using modeling approach can be done faster and with less cost compared with field experiments. However, the models must be calibrated to ensure that the model accurately simulates drainage outflow [11]. The common models being used to simulate tile drainage (e.g. GLEAMS [12], DRAINMOD [13], ADAPT [14], SWACROP [15] by, RZWQM [16], and SWAT [17] have not been tested in NL.

DRAINMOD was initially developed to help evaluate the performance of multi-component water management systems [13]. It is a field-scale, process-based, distributed model with broad applications such as predicting hydrology of poorly drained lands and surface runoff and ultimately, helping to optimize the design of drainage systems [18]. The model is based on the Hooghoudt's equation and water balance in terms of WTD and soil water content midway between parallel drain 
tiles. Based on weather, soil and crop data [19], DRAINMOD calculates infiltration, runoff, drainage, sub irrigation and evaporation on hourly and daily time scales as well as crop yield, nitrate leaching, and hydrological analysis of wetlands [7, 20]. DRAINMOD is relatively simple and easily adapted model to describe hydrology as compared to many other hydrologic models [21]. Using simple water balance equations which include simulates the agricultural hydrology based on the section of soil profile and soil surface and analyses the effectiveness of subsurface drainage systems.

While DRAINMOD [22] has been widely applied to drainage design and performance in agricultural fields in mild areas, the model underestimates the effects of soil freezing, and thawing [6]. Freezing and thawing processes [23] affect field hydrology, such as infiltration-runoff relationship during snow melting or rainfall. In particularly, the effects on field hydrology with low infiltration leading to high surface runoff happen during the later winter and early spring periods. However, DRAINMOD has modified to include prediction of soil temperature and snow accumulation/melting during freezing and thawing periods [18]. Basically, once the users provide the threshold temperature, initial snow depth and soil temperature, the model can predict the snow accumulation and melting process $[18,24]$. Therefore, the primary objective of this study was to evaluate the performance of DRAINMOD model for predicting drainage and WTD on several experimental agricultural plots under forages located in St. John's, Newfoundland, using drainage and soil parameters from previous studies. In achieving this, DRAINMOD was calibrated and validated using two years of field measurements. In this study, the measured outflow of 2017 was used for calibration and data of 2018 were used for validation. This primary calibration was based on parameters such as ET monthly factor, drainage coefficient, soil frozen temperature, vertical hydraulic conductivity, lateral saturated hydraulic conductivity, and soil surface storage. During the primary calibration process, the model performance was graphically evaluated by plotting measured and simulated values against time. Using statistical methods, the model was evaluated by calculating the average mean of difference. The adjusted parameters were then used for prediction during the validation using observed results in 2018.

\section{Materials and Methods}

\subsection{Study Site and Data Description}

The study site shown is located at the St. John's Research and Development Centre adjacent to Mount Pearl, Newfoundland $\left(47^{\circ} 31^{\prime \prime} \mathrm{N}, 52^{\circ} 47^{\prime \prime}\right.$ W) (Figure 1). This site, located on the Avalon Peninsula of Eastern Newfoundland, has a rolling landscape in Podzolic soils growing mixed forages with conventional subsurface drainage. The annual precipitation was $1489 \mathrm{~mm}$ and $1418 \mathrm{~mm}$ in 2017 and 2018, respectively. The highest monthly precipitation ( $265 \mathrm{~mm}$ ) occurred in September 2017 and in October 2018 (185 mm). Snow accumulates on the fields from December to February when temperatures are below $0^{\circ} \mathrm{C}$, and gradually melts in spring. 


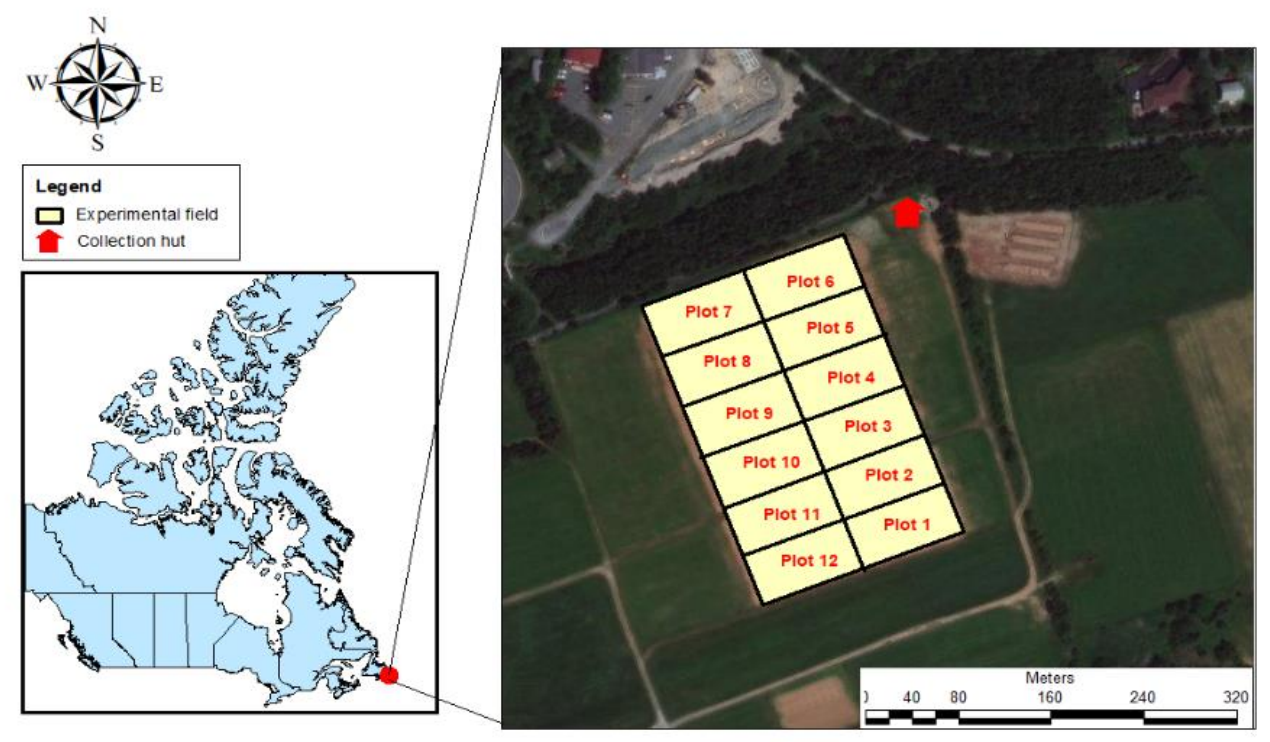

Figure 1 Location and aerial photo of experimental field.

The field was divided into twelve experimental $(32 \mathrm{~m} \times 60 \mathrm{~m}$ ) plots with two parallel drain lines installed at $1 \mathrm{~m}$ depth and $10 \mathrm{~m}$ spacing in each plot along with interceptor drain lines on plot borders as shown in Figure 2. There is a drain tile at bottom of each plot ensuring that all the drainage outflows were collected and transferred to a collection hut by PVC pipes. In the collection hut, the outflow volumes were measured continuously by tipping buckets (volume of $1 \mathrm{~L}$ ) (Figure 3 ). The action of each tipping event triggers a small switch and transmit the count to a data logger. The data loggers run 24/7 from 2017 to 2018, of which results were extracted every month. Eventually, the outflow volume from each plot was converted to depth $(\mathrm{cm})$ by dividing by the total plot area and the total outflow depth was obtained by summing all plot values.

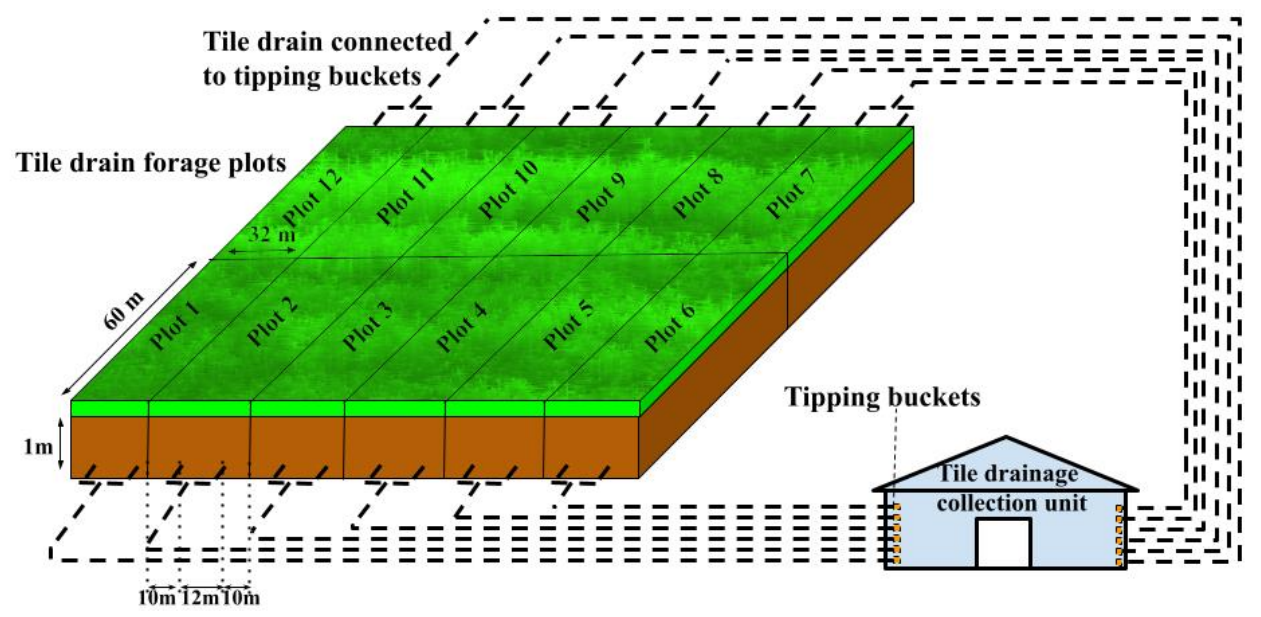

Figure 2 Schematic diagram of twelve experimental plots and tile drainage layout. 


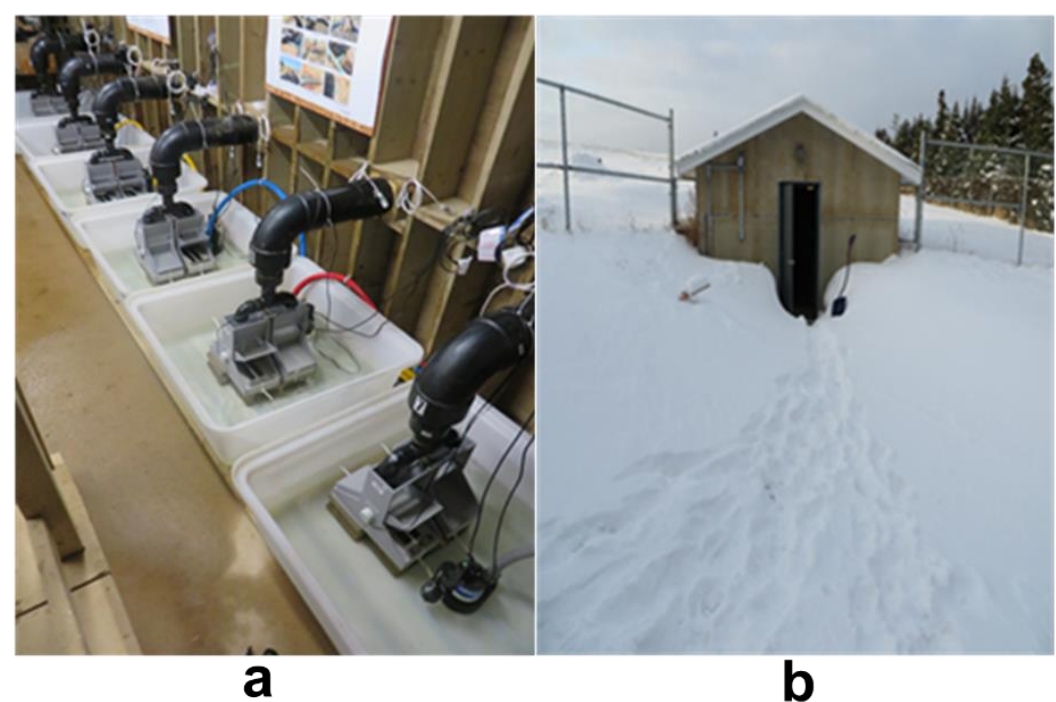

Figure 3 Tile drainage collection unit: (a) Tipping buckets; (b) View of drainage hut during snow period.

\subsection{Soil}

The characteristic of soil determines the infiltration rate, soil water storage, internal drainage and WTD. The soils of this site have developed on an acidic coarse textured glacial till and are predominantly members of the Cochrane series (well drained) with minor areas of the Pouch Cove series (imperfectly drained) [25] usually developed on coarse-textured, iron-rich, non-calcareous materials. The inherent productivity of Podzolic soils in Canada for agriculture is generally not high because of $\mathrm{pH}$ and fertility limitations due to high leaching. These soils are also limited regionally by unfavourable climate, and locally by stoniness, low water holding capacity, shallowness to bedrock or because of imperfect drainage associated with topographic position. Therefore, the Podzolic soils are used mainly for small grains or forage and pasture production with associated livestock [26].

\subsection{Crop}

The field experiment was planted in 2016 utilizing an incomplete Latin square design in three blocks with four types of forage mixtures identified as conventional grass, improved grass, conventional forage, and improved forage. The conventional grass mixture contained Richmond Timothy (Phleum pratense L.) and Preval Meadow Fescue (Festuca pratensis Huds.) which was planted at Plots 2, 5 and 9. The improved grass mixture included a forage legume and had AC Brador Alfalfa (Medicago sativa L.), Richmond Timothy (Phleum pratense L.), Yukon Tall Fescue (Festuca arundinacea Schreb.), and AC Success Bromegrass (Bromus inermis Leyss.), which was grown on Plots 1, 4 and 8. The rest of the plots were planted with pure stand AC Brador Alfalfa: Plots 6, 10 and 11 were managed conventionally similar to a selected local dairy farmer considered to be following conventional forage production practices, and Plots 3, 7, and 12 were managed as an improved forage crop. Liquid dairy manure at 55,000 L per ha was broadcast on the conventional grass and conventional forage plots, and it was surface applied on the improved grass and improved forage plots. Triplicate samples from each plot were sampled for forage yield and nutritive value, and for species composition from each of the forage mixtures. The results with respect to these 
treatment effects will be presented in a future research paper. For this study, only the effect of rooting depth on drainage modeling was taken into consideration.

\subsection{DRAINMOD Description}

DRAINMOD is a field-scale hydrologic model first developed by Skaggs R. W. [13] and widely applied in poorly drained agricultural lands [6]. It can simulate surface runoff, subsurface drainage, evapotranspiration (ET), infiltration and WTD (DRAINMOD 6.1). Water balance protocol of soil profile is the core of the model to calculate hydrologic output, which is applied from the impermeable layer up to the soil surface and midway between parallel drains. The water balance equations are given as follow:

$$
\begin{gathered}
\Delta V_{a}=D+E T+D S-F \\
P=F+R O+\Delta S
\end{gathered}
$$

where $\Delta V_{a}$ is the change in the water-free pore space or air volume $(\mathrm{cm}), \mathrm{D}$ is the lateral drainage $(\mathrm{cm}), E T$ is the evapotranspiration $(\mathrm{cm}), D S$ is the deep and lateral seepage $(\mathrm{cm}), F$ is infiltration $(\mathrm{cm})$, $P$ is the precipitation $(\mathrm{cm}), R O$ is the surface runoff $(\mathrm{cm})$ and $\Delta S$ is the change in surface water storage $(\mathrm{cm})$. By using the equations, subsurface drainage rates and surface runoff output can be obtained [6]. Infiltration is estimated using the Green-Ampt equation and deep seepage is estimated using Darcy's law. Potential evapotranspiration (PET) is calculated by the Thornthwaite equation. Heat index, location latitude, and daily maximum and minimum air temperature data are used to calculate PET. Additionally, DRAINMOD computes freezing and thawing in order to simulate the drainage processes in cold regions. When the daily maximum temperature is below a temperature assumed to divide rain and snow, daily precipitation is considered as snowfall and added to snow accumulation. When air temperature rises above a snowmelt base temperature, snowmelt is calculated by the water flow equation and heat flow equation as follows;

$$
\begin{gathered}
\frac{\partial \theta w}{\partial t}+\frac{\rho_{i}}{\rho_{w}} \frac{\partial \theta i}{\partial t}=\frac{\partial}{\partial z}\left[D(\theta w) \frac{\partial \theta w}{\partial z}\right]-\frac{\partial K(\theta w)}{\partial z} \\
C_{h} \frac{\partial \mathrm{T}}{\partial \mathrm{t}}=\frac{\partial}{\partial \mathrm{z}}\left(\lambda \frac{\partial \mathrm{T}}{\partial \mathrm{z}}\right)+\rho_{\mathrm{iL}} \frac{\partial \theta \mathrm{i}}{\partial \mathrm{t}}
\end{gathered}
$$

where $\mathrm{z}=$ vertical depth $(\mathrm{cm}) ; \mathrm{t}=$ time $(\mathrm{s}) ; \theta w=$ unfrozen water content $\left(\mathrm{cm}^{3} \mathrm{~cm}^{-3}\right) ; \theta i=$ ice content $\left(\mathrm{cm}^{3} \mathrm{~cm}^{-3}\right) ; \mathrm{D}(\theta w)=$ water diffusivity $\left(\mathrm{m}^{2} \mathrm{~s}^{-1} ; \mathrm{K}(\theta w)=\right.$ unsaturated soil hydraulic conductivity $\left(\mathrm{m} \mathrm{s}^{-1}\right) ;$ $\rho_{w}=$ density of water $\left(\mathrm{kg} \mathrm{m}^{-3}\right) ; \rho_{i}=$ density of ice $\left(\mathrm{kg} \mathrm{m}^{-3}\right) ; \mathrm{T}=$ temperature $\left({ }^{\circ} \mathrm{C}\right) ; \mathrm{L}=$ latent heat of freezing $\left(\mathrm{kJ} \mathrm{kg}^{-1}\right) ; C_{h}=$ volumetric specific heat of soil $\left(\mathrm{cal} \mathrm{m} \mathrm{m}^{-3} \mathrm{C}^{-1}\right)$; and $\lambda=$ thermal conductivity of soil $\left(\right.$ cal m $\left.\mathrm{m}^{-1} \mathrm{~s}^{-1}{ }^{\circ} \mathrm{C}^{-1}\right)[27,28]$.

\subsection{Model Inputs}

DRAINMOD requires information on drainage system design, soil physical properties, crop and weather data (precipitation, and maximum and minimum temperature) to estimate drainage outflow and WTD. The most important drainage parameters used in this DRAINMOD simulation are listed in Table 1 . The drain spacing and depth, distance from surface to impermeable layer, 
maximum surface storage, and Kirkham's depth were measured in situ. The effective radius of the drain tiles was $0.51 \mathrm{~cm}$ for a $0.1 \mathrm{~m}$ diameter corrugated pipe according to [1]. Drainage coefficient was estimated according to the DRAINMOD manual [28] and modified according to the measured drainage outflow. Based on these drainage system design parameters, DRAINMOD can automatically calculate the equivalent depth and Kirkham's coefficient. Crop parameters such as rooting depth, and the length of growing season were estimated by averaging different types of forage mixtures since detailed crop parameters were not available for this novel forage mixture. Soil hydraulic parameters were measured in situ. There are five layers of the soil profile at this field. Soil saturated hydraulic conductivity ( $\mathrm{K}_{\text {sat }}$ ) (Table 2 ) and volumetric water content curve (Figure 4 ) for individual layer are required as input data to DRAINMOD to produce the other soil data required.

Table 1 Model input parameters used in DRAINMOD.

\begin{tabular}{|c|c|c|c|}
\hline Category & Parameter & Value & Source \\
\hline Drainage & Depth of drain $(\mathrm{cm})$ & 100 & Field measurement \\
\hline \multirow[t]{11}{*}{ Parameters } & Spacing between drains $(\mathrm{cm})$ & 1000 & Field measurement \\
\hline & Effective radius $(\mathrm{cm})$ & 0.51 & [1] \\
\hline & $\begin{array}{ll}\text { Actual distance } & \text { to } \\
\text { impermeable layer }(\mathrm{cm}) & \end{array}$ & 200 & [1] \\
\hline & Drainage Coefficient (cm/day) & 1.7 & {$[1]$} \\
\hline & Initial WTD (cm) & 100 & Assumption \\
\hline & Maximum surface storage $(\mathrm{cm})$ & 2.5 & Assumption \\
\hline & Kirkham's depth (cm) & 1 & Assumption \\
\hline & Bottom width of ditch $(\mathrm{cm})$ & 60 & Field measurement \\
\hline & Ditch side slope (H: V) & 0.05 & Field measurement \\
\hline & Down slope & $2 \%$ & Field measurement \\
\hline & Length of slope (cm) & 22500 & Field measurement \\
\hline \multirow[t]{8}{*}{$\begin{array}{l}\text { Soil } \\
\text { Temperature }\end{array}$} & $\begin{array}{l}\text { Soil thermal conductivity } \\
\text { function }\end{array}$ & $\begin{array}{l}\text { TKA }=0.5 \\
\text { TKB }=1.5^{1}\end{array}$ & [1] \\
\hline & Computational depth function & $Z A=2.5, Z B=1.21^{2}$ & Default value \\
\hline & $\begin{array}{l}\text { Average air temperature below } \\
\text { which precipitation is snow }\left({ }^{\circ} \mathrm{C}\right)\end{array}$ & 0 & [1] \\
\hline & $\begin{array}{l}\text { Average air temperature above } \\
\text { which snow starts to melt }\left({ }^{\circ} \mathrm{C}\right)\end{array}$ & 2 & [1] \\
\hline & $\begin{array}{l}\text { Snow melt coefficient } \\
\text { (mm/day) }\end{array}$ & 5 & [1] \\
\hline & Critical ice content $\left(\mathrm{cm}^{3} / \mathrm{cm}^{3}\right)$ & 0.25 & [1] \\
\hline & $\begin{array}{l}\text { Diurnal phase lag of air } \\
\text { temperature }(\mathrm{h})\end{array}$ & 8 & {$[1]$} \\
\hline & $\begin{array}{l}\text { Soil temperature at the bottom } \\
\text { of the profile }\left({ }^{\circ} \mathrm{C}\right)\end{array}$ & 5.6 & $\begin{array}{l}\text { Calculated according to } \\
\text { weather data }\end{array}$ \\
\hline Weather & Thornthwaite latitude & 47.31 & Field measurement \\
\hline Parameters & Heat Index & 22.8 & $\begin{array}{l}\text { Calculated according to } \\
\text { weather data }\end{array}$ \\
\hline
\end{tabular}


${ }^{1}$ TKA, TKB: Soil thermal conductivity function; ${ }^{2}$ ZA, ZB: Computational depth functions.

Table 2 Texture and saturated hydraulic conductivity $\left(\mathrm{K}_{\text {sat }}\right)$ of different soil layers at experimental field on Brookfield Road, St. John's.

\begin{tabular}{llllll}
\hline Soil Layer & Depth $(\mathbf{c m})$ & Sand (\%) & Silt (\%) & Clay (\%) & $\mathbf{K}_{\text {sat }}(\mathbf{m m} / \mathbf{h})$ \\
\hline Ap & $0-20$ & 25 & 50 & 25 & 30.77 \\
Bf & $20-34$ & 59 & 29 & 12 & 53.08 \\
BC & $34-70$ & 76 & 22 & 2 & 162.82 \\
Cxj1 & $70-100$ & 66 & 32 & 2 & 153.70 \\
Cxj2 & $100-135$ & 63 & 31 & 6 & 112.95 \\
\hline
\end{tabular}

Input data included: Hourly precipitation and daily maximum and minimum temperatures for 2017 and 2018, collected from Environment and Climate Change Canada and latitude of the location. The PET was calculated by model based on Thornthwaite method using weather data and geographic location with monthly correction factors. The monthly factors used were; 1 for November to March, 3 for April and September, 2.2 for May, 1.5 for June, 1.1 for July and August, and 1.85 for October. DRAINMOD can predict drainage under the option of soil freezing and thawing condition, which requires; soil thermal conductivity coefficient, computational depth coefficient, average air temperature below which precipitation is snow and above which snow starts to melt, snow melt coefficient, critical ice content, diurnal phase lag of air temperature, and soil temperature at the bottom of the profile. The values were obtained based on previous research by Dayyani et al. [29] and historical weather data from Environment and Climate Change Canada. Weather data from 2016 was used as the warm-up period for the model in order to reduce initial system errors. All other parameters were kept as default values.

A summary of related modeling studies is given in Table 3. All of them provides result of hydrology such as daily drainage outflow and WTD but have different drainage design. The input parameters of this study were based on the field measurement and the model parameters were the same for all experimental plots.

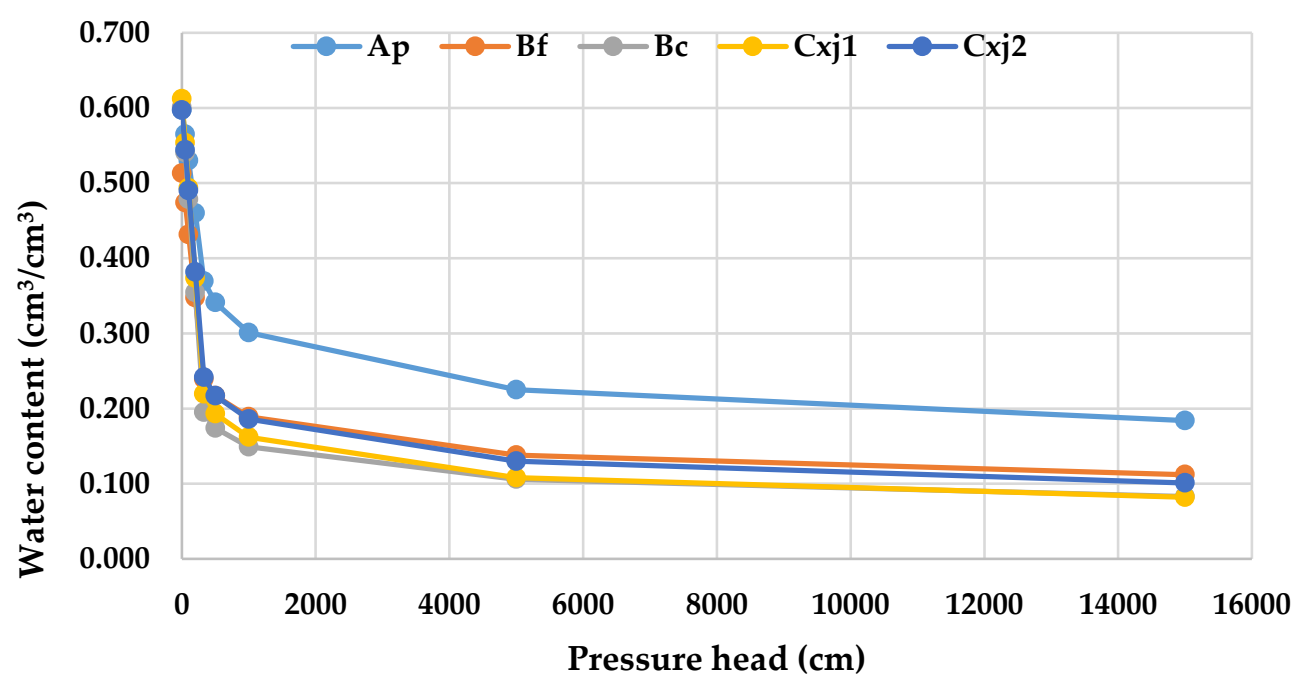

Figure 4 Soil moisture characteristics curves of Podzolic soil [25] 
Table 3 Summary of modeling agricultural land drainage studies using DRAINMOD.

\begin{tabular}{|c|c|c|c|c|c|c|c|c|c|c|}
\hline Location & $\begin{array}{l}\text { Research } \\
\text { Focus }\end{array}$ & $\begin{array}{l}\text { Experiment } \\
\text { Period }\end{array}$ & $\begin{array}{l}\text { Annual } \\
\text { Precipitation } \\
\text { (mm) }\end{array}$ & $\begin{array}{l}\text { Annual } \\
\text { Average } \\
\text { Temperature } \\
\left({ }^{\circ} \mathrm{C}\right)\end{array}$ & $\begin{array}{l}\text { Study } \\
\text { Area } \\
\text { (ha) }\end{array}$ & Soil type & Crop & $\begin{array}{l}\text { Tile } \\
\text { Spacing (m) }\end{array}$ & $\begin{array}{l}\text { Tile } \\
\text { Depth } \\
\text { (m) }\end{array}$ & $\begin{array}{l}\text { Refer } \\
\text { ence }\end{array}$ \\
\hline & & & & & $\begin{array}{c}\text { Site A - } \\
5.9\end{array}$ & $\begin{array}{c}\text { Rubicon } \\
\text { sandy loam }\end{array}$ & $\begin{array}{c}\text { Corn, alfalfa, } \\
\text { clover, and } \\
\text { grass }\end{array}$ & 13 & 1.0 & \\
\hline $\begin{array}{l}\text { Quebec, } \\
\text { Canada }\end{array}$ & $\begin{array}{l}\text { Hydrology } \\
\text { and } \\
\text { surface } \\
\text { runoff }\end{array}$ & $\begin{array}{l}2002- \\
2006\end{array}$ & 600 & 6.8 & $\begin{array}{c}\text { Site B - } \\
7.8\end{array}$ & $\begin{array}{l}\text { Sainte Rosalie } \\
\text { clay loam, } \\
\text { Suffield clay } \\
\text { loam, and } \\
\text { Bedford sandy } \\
\text { clay loam }\end{array}$ & $\begin{array}{c}\text { Corn, barley } \\
\text { and } \\
\text { soybeans }\end{array}$ & 10 & 1.0 & {$[6]$} \\
\hline $\begin{array}{l}\text { Manitoba } \\
\text {, Canada }\end{array}$ & $\begin{array}{l}\text { Hydrology } \\
\text { and potato } \\
\text { crop yield }\end{array}$ & $\begin{array}{l}2010- \\
2012\end{array}$ & 533 & 3.8 & $\begin{array}{c}44 \times 50 \\
m\end{array}$ & $\begin{array}{c}\text { Fine sandy } \\
\text { loam }\end{array}$ & Potato & 15 & 1.06 & [1] \\
\hline $\begin{array}{l}\text { Carsamb } \\
\text { a, Turkey }\end{array}$ & Hydrology & 1991 & 950 & 14.4 & 5 & $\begin{array}{l}\text { Silty clay and } \\
\text { loamy sand }\end{array}$ & $\begin{array}{l}\text { Winter } \\
\text { wheat }\end{array}$ & 25 & 1.0 & [18] \\
\hline $\begin{array}{l}\text { Truro, } \\
\text { Nova } \\
\text { Scotia, } \\
\text { Canada }\end{array}$ & $\begin{array}{l}\text { Hydrology } \\
\text { and } \\
\text { nitrogen- } \\
\text { leaching }\end{array}$ & $\begin{array}{l}1994- \\
1997\end{array}$ & 1182 & 6.0 & 3.5 & $\begin{array}{c}\text { Debert (75\%) } \\
\text { and Queens } \\
(25 \%)\end{array}$ & $\begin{array}{c}\text { Corn and } \\
\text { barley }\end{array}$ & 12 & 0.8 & [30] \\
\hline $\begin{array}{l}\text { Truro, } \\
\text { Nova } \\
\text { Scotia, } \\
\text { Canada }\end{array}$ & $\begin{array}{c}\text { Hydrology } \\
\text { and nitrate } \\
\text { loss }\end{array}$ & $\begin{array}{l}2003- \\
2006\end{array}$ & - & - & 6 & $\begin{array}{c}\text { Pagwash } 52 \\
\text { soils have } 50- \\
80 \mathrm{~cm} \text { of } \\
\text { friable, coarse } \\
\text { loamy solum } \\
\text { over firm, }\end{array}$ & Corn & 12 & 0.8 & [31] \\
\hline
\end{tabular}




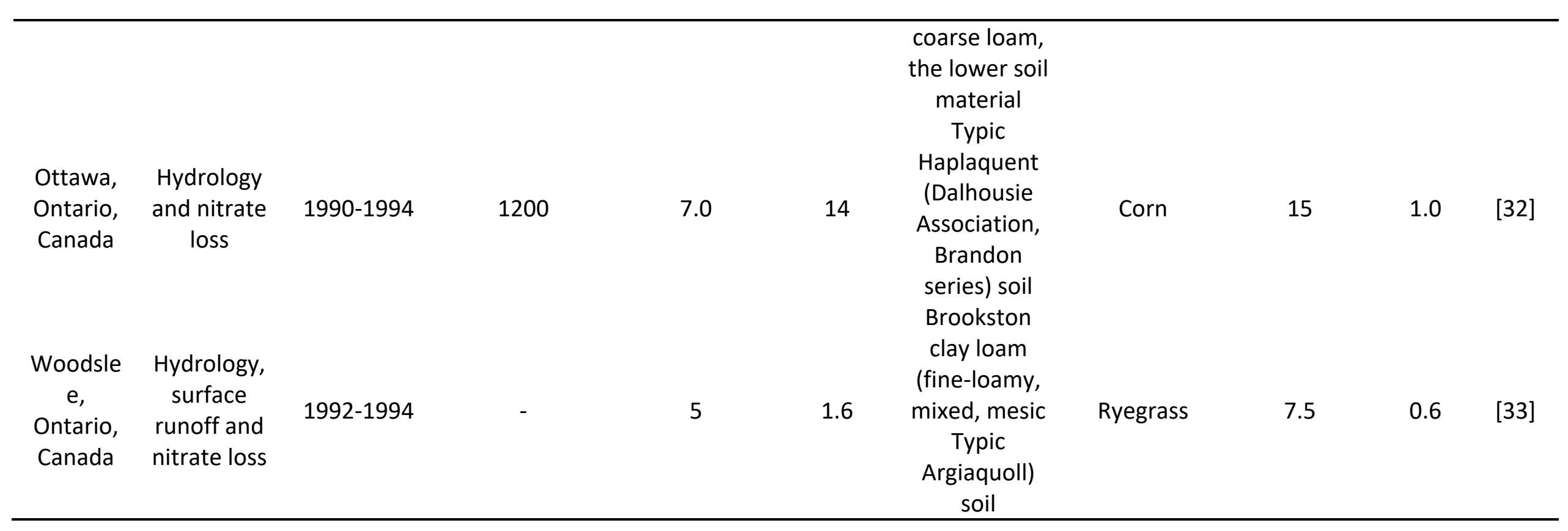




\subsection{Methods of Evaluation}

The evaluation for model predicting accuracy was done by graphical and statistical methods. During graphical method, predicted and measured drain outflow were plotted together and the agreement between these two would be vividly presented. The statistical analysis was calculated the following parameters: root mean square error (RMSE), mean absolute error (MAE), and index of agreement (IOA).

$$
\begin{gathered}
\text { RMSE }=\sqrt{\frac{1}{n} \sum_{i=1}^{n}\left(P_{i}-O_{i}\right)^{2}} \\
\text { MAE }=\frac{\sum_{i=1}^{n}\left|\left(P_{i}-O_{i}\right)\right|}{n} \\
I O A=1-\frac{\sum_{i=1}^{n}\left(P_{i}-O_{i}\right)^{2}}{\sum_{i=1}^{n}\left(\left|O_{i}-\bar{O}\right|+\left|P_{i}-\bar{O}\right|\right)^{2}}
\end{gathered}
$$

Where $\mathrm{O}_{i}$ and $\mathrm{P}_{\mathrm{i}}$ are $\mathrm{i}^{\mathrm{i} \text { th }}$ values of the observed and predicted values of drain outflow, $\overline{\mathrm{O}}$ is the average of observed values, and $\mathrm{n}$ is the number of values being calculated. According to Skaggs et al. [20], the RMSE and MAE should be closer to zero to indicate better fit between measured and predicted values. The best model would have IOA equal to 1 and smaller values mean inferior fit [1].

\section{Results}

The field was allocated to conduct research on four forage treatments with triplicate plots. Treatments 1, 2, 3 and 4 were respectively planted and managed as conventional grass plots, improved grass plots, conventional forage plots, and improved forage plot. It was observed that the performance of the model for each treatment were different which is shown on a time series plot of measured and predicted values (Figure 5). In this study, the DRAINMOD model predicted WTD and drain outflow based on the equivalent soil and crop parameters for four treatments. However, there were various factors affecting drain flow such as crops types, management methods, slope and landscape. Results of the DRAINMOD model evaluation in predicting drain outflow showed that there was an acceptable agreement between predicted and observed drain outflow with an IOA of 0.559 and a MAE of $0.301 \mathrm{~cm}$ overall. The WTD was successfully simulated through the year, which is beneficial for farmers to optimize irrigation and enhance yield of crops not only for rainfall season but also for the snow melting period. Since it was the first attempt in Newfoundland, the objective was to verify the practicability of DRAINMOD simulation in agricultural drainage. With detailed landscape, soil and crop data, better accuracy will be achieved with improved model calibration followed by validation using more observed data. 

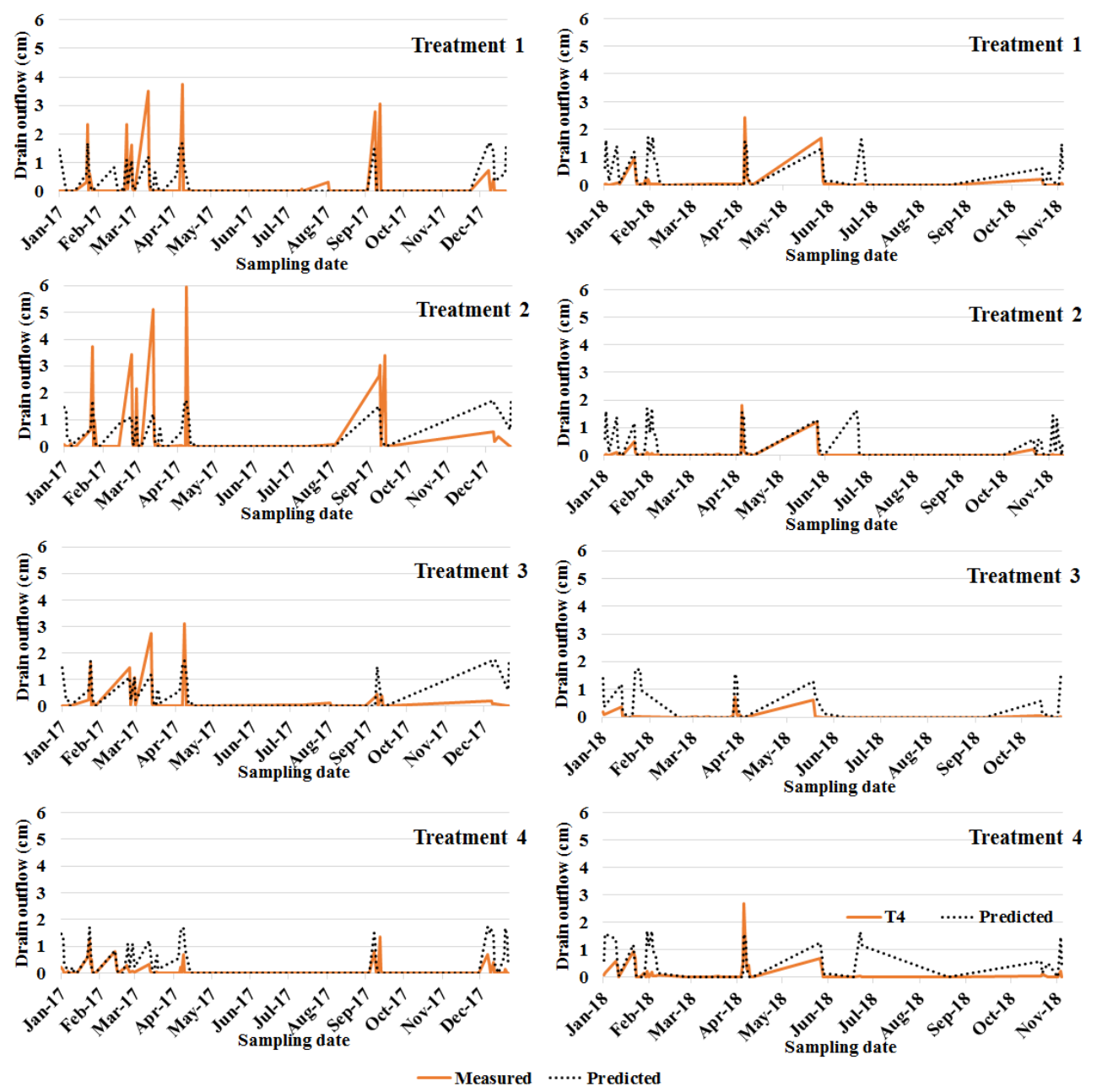

Figure 5 Comparison of measured and predicted drain outflow $(\mathrm{cm})$ averaged across replicates for each experimental treatment: (a) comparison graph of 2017; (b) comparison graph of 2018.

During spring, snowmelt and rainfall were both contributing to the increase of drain outflow. Snowmelt estimation depends on the change of air temperature. The ratio of snowmelt and rainfall led to the uncertainty of drain outflow drainage prediction. From Figure 5 (a), the model was underpredicting during spring for Treatment 1, 2 and 3 but over-predicting for Treatment 4 in 2017. There was no observation during summer, as the soil was dry due to the high ET. A heavy rainfall event followed in September, but the model was able to predict the timing for all treatments since the volume was distributed differently potentially because of the uneven landscape. However, the overall drain outflow agreed with the predicted value during this rainfall event. In winter of 2017, the model was over-predicting for all treatments, especially Treatment 3 which measured the least drain outflow. On the other hand, in 2018, the observed drain outflow was lower than predicted values during spring time. There was a sudden snowmelt event at the end of January which triggered drainage flow, when DRAINMOD successfully predicted the drain outflow for Treatment 1 and 4. Generally snowmelt happened in April and led to significant drainage as the soil was already saturated by snowmelt. In this case, DRAINMOD was accurately predicting the drainage flow event for Treatment 2 from April to June. 
Figure 6 shows the daily measured and predicted drain outflow during 2017 and 2018. The measured drain outflow was predicted more accurately in 2017 than 2018 from January to April. Because the heat index and snowmelt divided temperature data were different from year to year, however, the model was using the same parameters for both years when simulating. In 2018, the model was able to predict the flow event after snowmelt. Nevertheless, the model still requires calibration and modification on prediction during winter when soil is frozen.

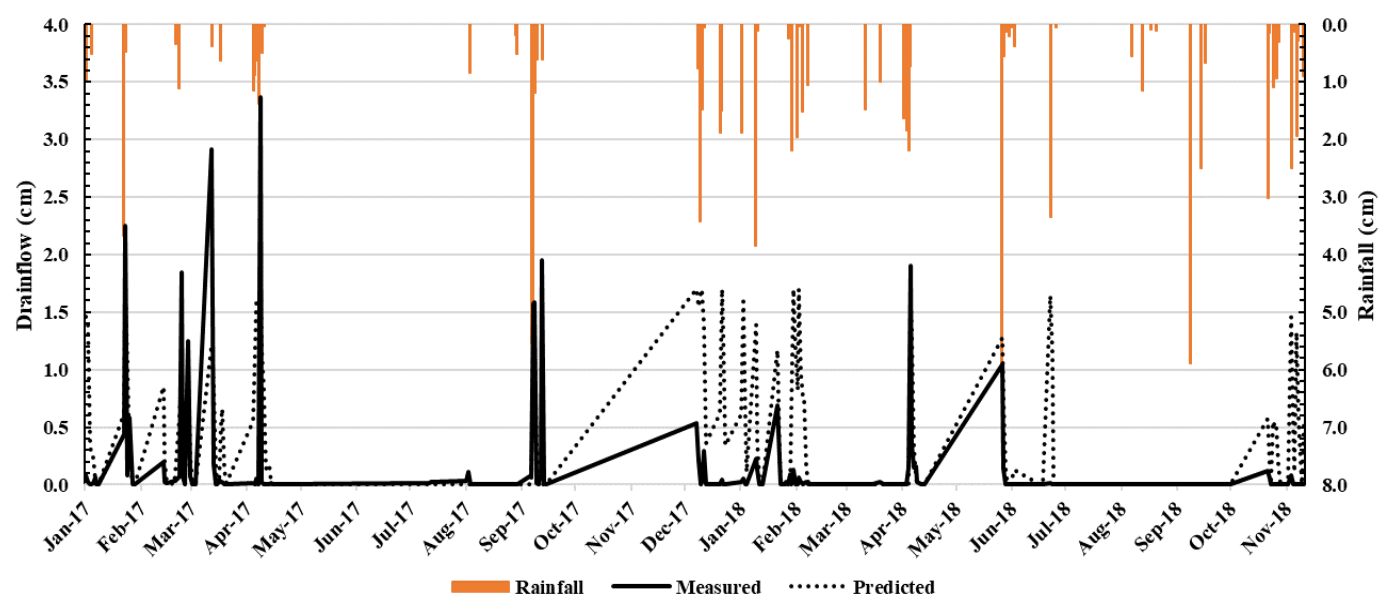

Figure 6 Total measured and predicted drain outflow $(\mathrm{cm})$ and rainfall $(\mathrm{cm})$ in 2017 and 2018.

The data were filtered by the total measured drainage outflow. Only the dates with positive drainage were selected to conduct statistical analysis. The summary of statistical analysis for drainage outflow of 2017 and 2018 are given in Table 4. The RMSE was $0.627 \mathrm{~cm}$ for all four treatments in 2017 and $0.501 \mathrm{~cm}$ in 2018, which is mainly due to the uncertainty when simulating drainage during winter when soil is frozen. The IOA ranged between 0.416 to 0.588 for different treatments and the highest result reached to 0.600 for overall treatments in 2017 . From the result of 2018, IOA was 0.559 for all treatments which slightly lower than result of previous year. Treatment 3 recorded the least IOA due to lack of days with drain outflow observed. RMSE fell into small range from 0.529 to 0.658 , which indicated less variation between treatments. Throughout the two years of observation, IOA was 0.559 with MAE of $0.301 \mathrm{~cm}$. The result was considered to have acceptable accuracy for the DRAINMOD model. Since the model was the first attempt in Newfoundland there was a lack of background information for detailed calibration. The uneven landscape of each plot resulted in variation of drainage distribution. Besides, this model did not input distinguishing parameters for different crops and management methods which is highly recommended for future research.

Table 4 Summary of statistical analysis for daily drain outflow prediction by DRAINMOD.

\begin{tabular}{llcccc}
\hline \multirow{2}{*}{ Year } & \multicolumn{3}{c}{ Statistic } & \multirow{2}{*}{ No. of days with drain outflow (days) } \\
\hline \multirow{2}{*}{2017 RMSE $(\mathrm{cm})$} & MAE $(\mathrm{cm})$ & IOA & 68 \\
& Treatment 1 & 0.828 & 0.498 & 0.588 & 67 \\
& Treatment 2 & 1.125 & 0.648 & 0.507 & 48 \\
\hline
\end{tabular}




\begin{tabular}{|c|c|c|c|c|c|}
\hline & Treatment 4 & 0.637 & 0.404 & 0.416 & 78 \\
\hline \multirow{7}{*}{2018} & All treatments & 0.627 & 0.345 & 0.600 & 107 \\
\hline & Treatment 1 & 0.658 & 0.400 & 0.475 & 52 \\
\hline & Treatment 2 & 0.529 & 0.276 & 0.401 & 95 \\
\hline & Treatment 3 & 0.611 & 0.333 & 0.354 & 39 \\
\hline & Treatment 4 & 0.589 & 0.353 & 0.553 & 56 \\
\hline & All treatments & 0.501 & 0.255 & 0.445 & 101 \\
\hline & Overall & 0.570 & 0.301 & 0.559 & 208 \\
\hline
\end{tabular}

Figure 7 shows the predicted water depth generated by DRAINMOD and plotting with daily rainfall data. During the spring, the highest WTD started to decrease until the rainfall season began. Started from June, WTD gradually increased and reached to $156.9 \mathrm{~cm}$ on August $7^{\text {th }}$. The range of WTD was around $140 \mathrm{~cm}$ to $160 \mathrm{~cm}$ during rainfall season. In 2018, the WTD predicted by DRAINMOD was more fluctuated due to the particular drought period in March and extreme high rainfall event on May $30^{\text {th }}$ (Figure $\left.7(\mathrm{~b})\right)$. The peak of the line reached to $165.5 \mathrm{~cm}$ on September $8^{\text {th }}$ and had the same range as 2017 during the rainfall season. DRAINMOD can simulate WTD not only for the rainfall season but also for the snow melting period, which is beneficial for farmers to optimize irrigation and enhance yield of crops. Singh et al. [11] investigated the impact of different drainage designs for lowa's tile landscapes. Research results indicated that a drainage intensity $(0.46$ $\mathrm{cm}$ day $\left.{ }^{-1}\right)$ with drain depth $(1.05 \mathrm{~m})$ and drain spacing $(25 \mathrm{~m})$ is good enough to maximize crop production and minimize nitrate nitrogen loss.

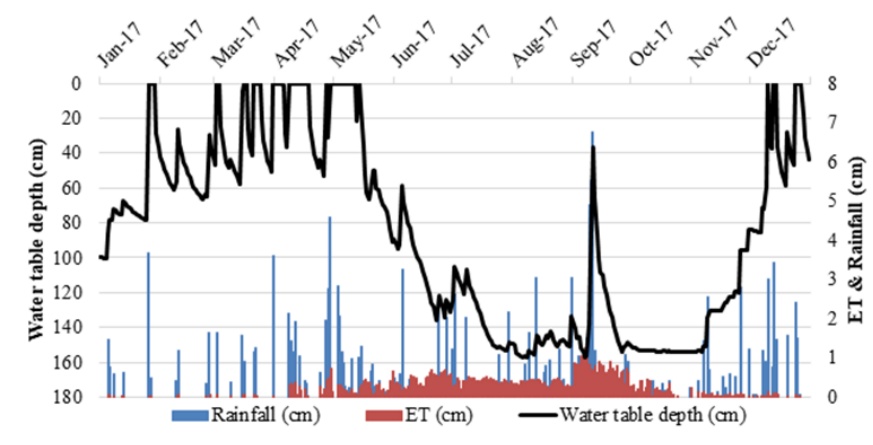

a

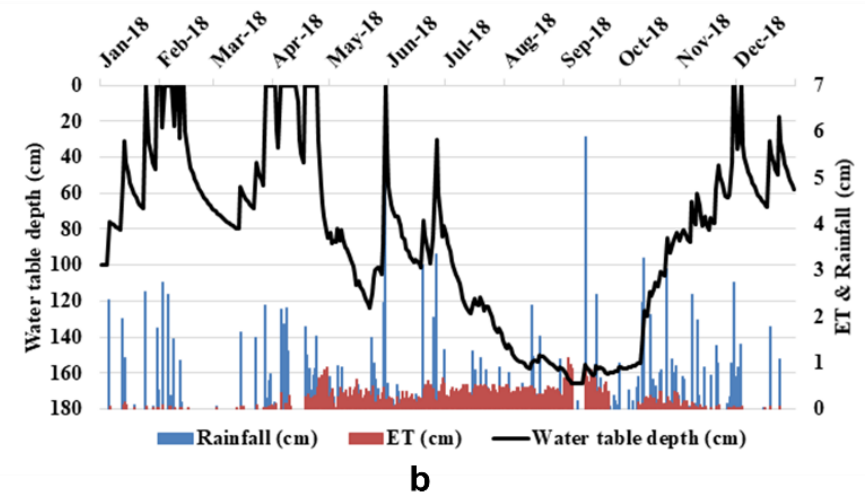

Figure 7 Predicted WTD $(\mathrm{cm})$, ET $(\mathrm{cm})$ and rainfall $(\mathrm{cm})$ : (a) time series graph of 2017; (b) time series graph of 2018. 


\section{Discussion}

The results presented above provide a clear insight into tile drainage outflow under Podzolic soil conditions, St. John's, NL. Data gathered from the tipping bucket with the help of data loggers were used for statistical analysis when assessing the accuracy of model predicted values. Other data such as weather conditions, soil and crop were incorporated in the model. The forage field subsurface outflow performance expressed through RMSE, MAE and IOA emphasizes the strength of the model simulation in the boreal environment. Generally, there was a good agreement between observed and predicted drain flow volumes collected from the forage field. In 2017, the model was under predicted three treatments of the forage field whereas the treatment four was over predicted. Chikhaoui et al. [34] stated about over estimation of subsurface drainage is mainly due to lack of consideration for macropore flow in the model. Similarly, DRAINMOD over predicted the peak values of huge drainage events [22]. The average absolute deviation represents the predicted value is different from the measured value on an average. Satchithanantham and Ranjan [1] evaluated drainage flow and WTD at Manitoba under cold climatic conditions. It was reported that the statistical analysis and visual comparisons using DRAINMOD predicted both WTD and flow rate with reasonable accuracy. Poor simulations were reported in DRAINMOD modeling under spring snowmelt conditions due to exceptionally high flows observed in the Pike River watershed, Montreal, Quebec [6]. Research conducted at a commercially operated farm at Manitoba indicates higher PET than the precipitation during the growing season [1].

Although the similar trends happened in 2018 model simulation, but the model predicted well during the snow melt event. The predicted and measured results of drainage for all plots based on treatments (Figure 5(a) \& 5(b)) show a good agreement between predicted and observed values. One of the reasons behind behaviour could be that the observed outflows were measured by using tipping buckets and the limitation of tipping frequency might have caused flow volume underestimated. In 2017, a higher drain outflow was observed during spring when the snowmelt happened and resulted a saturated soil profile and shallow water table. On the other hand, there was no observed flow during summertime potentially due to the high ET from the soil profile. Any rain occurred during this time was stored in the soil profile rather than deep drainage. There was another heavy precipitation caused high outflow during the winter. Luo et al. in 2001 reported that the DRAINMOD predicted the timing of most of the flow events whereas winter flow predictions showed decreased trend and the spring flow indicated increased trend [16]. These changes in prediction is probably due to pattern of precipitation is unusual in Truro and the same trend applies to Newfoundland weather pattern. In the study of Satchithanantham and Ranjan [1], there was no flow observed in winter because the ground was frozen and prevent infiltration. According to the temperature line graph on Figure 8 , the average temperature was above $0{ }^{\circ} \mathrm{C}$ from October to December while it was below $0{ }^{\circ} \mathrm{C}$ from January to April, which means the DRAINMOD can effectively estimate the drain outflow at the scenario of soil freezing and thawing. In 2018, there were only a few dates with observed high drainage outflows. Even though the overall model was over-estimating the outflow, the timing of peak was matched when extreme rainfall event happened. MACRO, Toot Zone Water Quality Model and HYDRUS-ID/2D are the frequently used models for predicting soil water movement but these models have limitations to apply to smaller fields due to lack of information on climate and soil for each small plot separately [35]. 


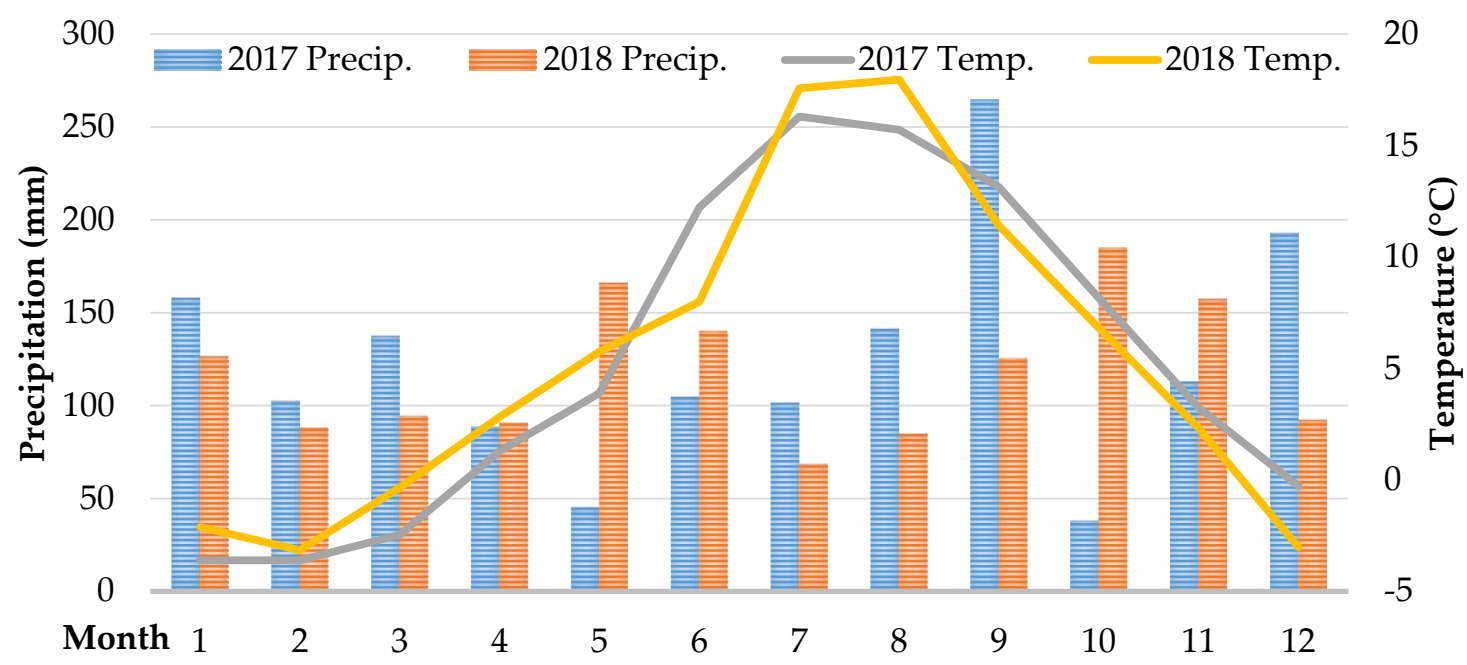

Figure 8 Mean monthly temperature and precipitation of 2017 and 2018.

DRAINMOD has been evaluated in the past by many researchers in different countries $[2,6,11$, 36]. Most of the researchers reported that the model simulation had a major influence on soil characteristics, rising and falling water tables, drain spacing and proper identification of input parameters. This study was conducted in an uneven field with a varying slope and therefore the model predictions have a different degree of agreement as compared to the measured values.

In 2017, Treatment 1 and 2 observed drainage outflow as twice as that in Treatment 3 and 4 . It is mainly because the uneven landscape, the amount of drainage depends on where the plots were located. The plots with higher elevation and steeper slope are expected to have lower drainage outflow. The variation of observed outflow in different plots leads to the over-prediction of model. Moreover, the data used in the DRAINMOD model represents the average slope of the whole field. This could have caused some errors in the predicted values due to the uneven slope within each individual plots. To solve this issue, the slope and landscape details of each plot are needed for model input. Then, each plot can be simulated individually to obtain better model results. Although DRAINMOD predicted reasonably well, especially snowmelt period, still certain limitations exist in overall effectiveness. One other reason might be Podzolic soil's poor drainage characteristic [6]. Partial winterkill of the alfalfa makes it difficult to predict if there were plot differences in crop water uptake. Moreover, the frequent freeze-thaw cycles at Newfoundland may change the pattern of subsurface drainage and surface runoff behaviour [37]. Subsequently, freeze-thaw events release melted water to tile drains through infiltration and percolation [38]. Therefore, the performance of the model seems to be satisfactory and has the ability to simulate the outflow for Podzolic soil [26] in Newfoundland.

\section{Conclusions}

DRAINMOD is a field scale model widely used in simulating hydrology for poorly drained soil or agricultural lands. This study is the first attempt in Newfoundland. St. John's is located on the Avalon Peninsula in Eastern Newfoundland with a rolling landscape and predominantly poorly drained Podzolic soils. This study used DRAINMOD to simulate WTD and subsurface tile drainage outflow on replicated experimental plots growing four types of forage mixtures in 2017 and 2018. The 
simulated WTD ranged from $140 \mathrm{~cm}$ to $160 \mathrm{~cm}$ during rainfall season. Besides, DRAINMOD can simulate WTD for snow melting periods, which is valuable for farmers to optimize irrigation. The performance of the model was statistically evaluated by RMSE, MAE and IOA. The RMSE was 0.627 $\mathrm{cm}$ for all four treatments in 2017 and $0.501 \mathrm{~cm}$ in 2018. RMSE of 2018 fell into a small range from 0.529 to 0.658 , which indicated less variation between treatments. The IOA ranged between 0.416 to 0.588 for different treatments and the highest result reached to 0.600 for overall treatments in 2017. From the result of 2018, IOA was 0.559 for all treatments. Throughout the two years of observation, IOA was 0.559 with MAE of $0.301 \mathrm{~cm}$. Generally, the DRAINMOD was able to predict drain outflow patterns with reasonable accuracy. During the rainy winter season, drain outflow was over-predicting because of errors associated with the tipping bucket used to track drainage flow. The uneven landscape might have contributed to the over-prediction of the model as well. However, the model successfully simulated drain outflow during the spring snow melting period. This period is critical for farmers for planning seeding and irrigation at the beginning of the growing season. The result of this study could be applied to different drainage design parameters to optimize the agricultural drainage systems and efficient water management decisions in Newfoundland. Better accuracy will be achieved with improved model calibration followed by validation using more observed data together with using detailed landscape, soil and crop data.

\section{Acknowledgments}

We thank Mr. Gary Bishop, Agricultural Engineer (Retired) from the St. John's Research and Development Centre who installed the tile drainage system in our experimental plots. The authors would also like to thank Ms. Sarah Leonard, Ms. Dena Wiseman and Mr. Chris Gibson who provided insight and expertise that greatly assisted the research. Special thanks to Dr. Linda Jewell for her suggestions on preparing the manuscript as well as her assistance in editing the manuscript. We are also immensely grateful to Mr. Adam Farrow who assisted us to arrange the data for model evaluation and simulation. A very special thanks to Dr. Skaggs and the team at the Department of Biological \& Agricultural Engineering, North Carolina State University, Raleigh for developing and allowing us to use DRAINMOD free of charge.

\section{Author Contributions}

Dr. Lordwin Jeyakumar designed the new drainage collection unit and collected the outflow data for the period of two years. Thereafter, Dr. Jeyakumar and his team analyzed the data and drafted the manuscript. Dr. David McKenzie was responsible for the overall function of the project and contributed significantly in field arrangements and manuscript preparation. Ms. Yuanmei Zhang gave assistance to Dr. Jeyakumar and Dr. McKenzie in data analysis and manuscript preparation. Dr. Lakshman Galagedara introduced the DRAINMOD model to our research team and provided assistance continuously in all phases of the project. Dr. Galagedara also visited the field site and helped the team in data collection and analysis. Dr. Shabtai Bittman was the Principal Investigator of the National Project on "Improving nutrient balances on dairy farms using model farmlets and simulation". Dr. Bittman provided constructive ideas and suggestions throughout the duration of the project. Moreover, Dr. Bittman reviewed and edited this manuscript. Mr. Derek Hunt provided project administration and technical support. 


\section{Funding}

This research was funded by Agriculture and Agri-Food Canada (Project \# J-001403).

\section{Competing Interests}

The authors have declared that no competing interests exist.

\section{References}

1. Satchithanantham S, Ranjan RS. Evaluation of DRAINMOD for potato crop under cold conditions in the Canadian Prairies. Trans ASABE. 2015; 58: 307-317.

2. Qi ZM, Singh R, Helmers MJ, Zhou XB. Evaluating the performance of DRAINMOD using soil hydraulic parameters derived by various methods. Agric Water Manag. 2015: 155; 48-52.

3. Prasher SO, Madani A, Clemente RS, Geng GQ, Bhardwaj A. Evaluation of two water table management models for Atlantic Canada. Agric Water Manag. 1996; 32: 49-69.

4. Golmohammadi G, Rudra RP, Parkin GW, Kulasekara PB, Macrae M, Goel PK. Assessment of impacts of climate change on tile discharge and nitrogen yield using the DRAINMOD model. Hydrology. 2021; 8: 1.

5. Malota M, Senzanje A. Modelling mid-span water table depth and drainage discharge dynamics using DRAINMOD 6.1 in a sugarcane field in Pongola, South Africa. Water SA. 2015; 41: 325-334.

6. Morrison J, Madramootoo CA, Chikhaoui M. Modeling agricultural land drainage under spring snowmelt conditions with DRAINMOD. Can J Civ Eng. 2014; 41: 275-284.

7. Gupta GP, Prasher SO, Madani A, Tejawat CM. Field validation of DRAINMOD in Atlantic Canada. CSAE Paper. 1992; 92-107.

8. Ballantine DJ, Tanner CC. Controlled drainage systems to reduce contaminant losses and optimize productivity from New Zealand pastoral systems. New Zealand J Agric Res. 2013; 56: 171-185.

9. Madramootoo CA, Helwig TG, Dodds GT. Managing water tables to improve drainage water quality in Quebec, Canada. Trans ASAE. 2001; 44: 1511-1519.

10. Brevé MA, Skaggs RW, Parsons JE, Gilliam JW. DRAINMOD-N, a nitrogen model for artificially drained soil. Trans ASAE. 1997; 40: 1067-1075.

11. Singh R, Helmers MJ, Qi ZM. Calibration and validation of DRAINMOD to design subsurface drainage systems for lowa's tile landscapes. Agric Water Manag. 2006; 85: 221-232.

12. Leonard RA, Knisel WG, Still DA. GLEAMS: Groundwater loading effects of agricultural management systems. Trans ASAE. 1986; 30: 1403-1418.

13. Skaggs RW. A water management model for shallow water table soils. Raleigh, NC: Water Resources Research Institute of the University of North Carolina; 1978; 134.

14. Ward AD, Alexander CA, Fausey NR, Dorsey JD. The ADAPT agricultural drainage and pesticide transport model. American Society of Agricultural Engineers. 1988.

15. Feddes RA, Kabat $P$, Van Bakel $P$, Bronswijk JJ, Halbertsma J. Modelling soil water dynamics in the unsaturated zone-state of the art. J Hydrol. 1988; 100: 69-111.

16. Decoursey DG, Rojas KW. A Root Zone Water Quality Model (RZWQM). Proc Symp Towards Sustainable Agri Great Plains. 1988. 
17. Arnold JG, Allen PM, Bernhardt G. A comprehensive surface-groundwater flow model. J Hydrol. 1993; 142: 47-69.

18. Luo W, Skaggs RW, Madani A, Cizikci S, Mavi A. Predicting field hydrology in cold conditions with DRAINMOD. Trans ASAE. 2001; 44: 825-834.

19. Askar MH, Youssef MA, Chescheir GM, Negm LM, King KW, Hesterberg DL, et al. DRAINMOD Simulation of macropore flow at subsurface drained agricultural fields: Model modification and field testing. Agric Water Manag. 2020; 242: 106401.

20. Helwig TG, Madramootoo CA, Dodds GT. Modelling nitrate losses in drainage water using DRAINMOD 5.0. Agric Water Manag. 2002; 56: 153-168.

21. Skaggs RW, Youssef MA, Chescheir GM. DRAINMOD: Model use, calibration, and validation. Trans ASABE. 2012; 55: 1509-1522.

22. Sands GR, Jin CX, Mendez A, Basin B, Wotzka P, Gowda P. Comparing the subsurface drainage flow prediction of the DRAINMOD and ADAPT models for a cold climate. Trans ASAE. 2003; 46: 645-656.

23. Enright $P$, Madramootoo CA. Phosphorus losses in surface runoff and subsurface drainage waters on two agricultural fields in Quebec. St. Joseph: American Society of Agricultural and Biological Engineers; 2004. DOI: 10.13031/2013.15722.

24. Dayyani S, Madramootoo CA, Prasher SO, Madani A, Enright P. Modeling water table depth, drain outflow, and nitrogen losses in a cold climate using DRAINMOD 5.1. Trans ASABE. 2010; 53: 385-395.

25. Woodrow EF, Croix RS, Wang C, Rees HW, McKenzie D, Bishop G, et al. Soil quality evaluation program interim report. Research Branch, St. John's: Agriculture Canada; 1996.

26. Clayton JS. Soils of Canada: A cooperative project of the Canada soil survey committee and the soil research institute (Vol. 1). Ottawa, Ontario: Research Branch, Canada Dept. of Agriculture; 1977.

27. Fuchs M, Campbell GS, Papendick RI. An analysis of sensible and latent heat flow in a partially frozen unsaturated soil 1. Soil Sci Soc Am J. 1978; 42: 379-385.

28. Skaggs RW. Methods for design and evaluation of drainage-water management systems for soils with high water tables. DRAINMOD Reference Rep. 1981.

29. Dayyani S, Madramootoo CA, Enright P, Simard G, Gullamudi A, Prasher SO, et al. Field evaluation of DRAINMOD 5.1 under a cold climate: Simulation of daily midspan water table depths and drain outflows 1. J Am Water Resour Assoc. 2009; 45: 779-792.

30. Gordon R, Madani A, Boyd N, Astatkie T, Jamieson R, Caldwell K. Subsurface Nitrate-N leaching loss as affected by drainage size and depth in a shallow slowly-permeable soil. Can Water Resour J. 2000; 25: 331-341.

31. Garmdareh SE, Malekian R, Madani A, Gordon R. Simulation of Nitrate-N leaching in No-till fields with DRAINMOD-N II in a cold-humid region. Irrig Drain. 2018; 67: 65-72.

32. Golmohammadi G, Rudra RP, Prasher SO, Madani A, Goel PK, Mohammadi K. Modeling the impacts of tillage practices on water table depth, drain outflow and nitrogen losses using DRAINMOD. Comput Electron Agric. 2016; 124: 73-83.

33. Yang CC, Prasher SO, Wang S, Kim SH, Tan CS, Drury C, et al. Simulation of nitrate-N movement in southern Ontario, Canada with DRAINMOD-N. Agric Water Manag. 2007; 87: 299-306. 
34. Chikhaoui M, Madramootoo CA, Eastman M, Michaud A. Estimating preferential flow to agricultural tile drains. In 2008 Providence, 2008 June 29-July 2; Rhode Island. St. Joseph: American Society of Agricultural and Biological Engineers. doi: 10.13031/2013.24812.

35. Kuzmanovski V, Trajanov A, Leprince F, Džeroski S, Debeljak M. Modeling water outflow from tile-drained agricultural fields. Sci Total Environ. 2015; 505: 390-401.

36. Tait R, Madramootoo CA, Enright $P$. An instrumented, field-scale research facility for drainage and water quality studies. Comput Electron Agric. 1995; 12: 131-145.

37. Henry HA. Climate change and soil freezing dynamics: Historical trends and projected changes. Clim Change. 2008; 87: 421-434.

38. Zheng $X Q$, Van Liew MW, Flerchinger GN. Experimental study of infiltration into a bean stubble field during seasonal freeze-thaw period. Soil Sci. 2001; 166: 3-10.

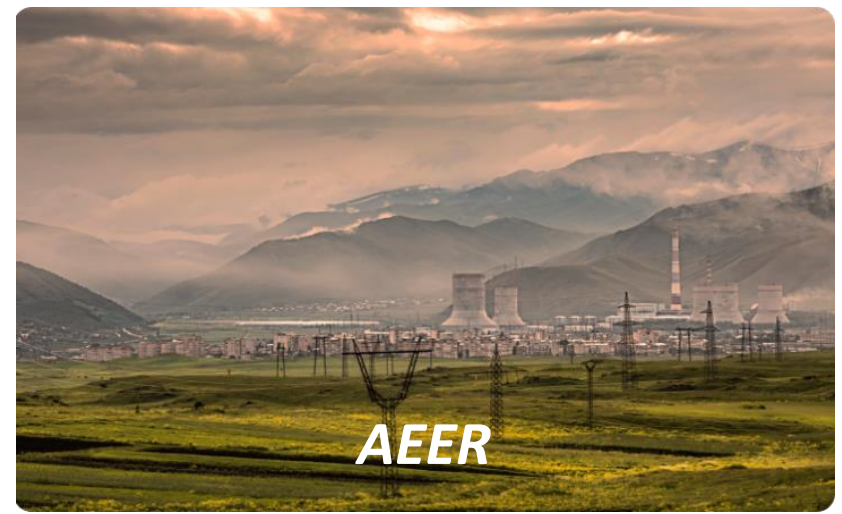

Enjoy $A E E R$ by:

1. Submitting a manuscript

2. Joining in volunteer reviewer bank

3. Joining Editorial Board

4. Guest editing a special issue

For more details, please visit:

http://www.lidsen.com/journals/aeer 